\title{
Microspectroscopic visualization of how biochar elevates the soil organic carbon ceiling
}

\section{Zhe (Han) Weng}

University of Queensland

Lukas Van Zwieten ( $\square$ lukas.van.zwieten@dpi.nsw.gov.au )

NSW Department of Primary Industries https://orcid.org/0000-0002-8832-360X

\section{Michael Rose}

NSW Department of Primary Industries

Bhupinder Pal Singh

NSW Department of Primary Industries

Ehsan Tavakkoli

NSW Department of Primary Industries

\section{Stephen Joseph}

University of New South Wales

\section{Lynne Macdonald}

CSIRO

\section{Stephen Kimber}

NSW Department of Primary Industries

\section{Stephen Morris}

NSW Department of Primary Industries

\section{Terry James Rose}

Southern Cross University

\section{Bráulio Archanjo}

Instituto Nacional de Metrologia, Qualidade e Tecnologia

\section{Caixian Tang}

La Trobe University

\section{Ashley Franks}

La Trobe University https://orcid.org/0000-0003-1664-6060

\section{Hui Diao}

The University of Qld

\section{Peter Kopittke}

The University of Queensland https://orcid.org/0000-0003-4948-1880

\section{Annette Cowie}

NSW Department of Primary Industries / University of New England https://orcid.org/0000-0002-3858- 


\section{Article}

Keywords: soil carbon, soil organic carbon, biochar

Posted Date: September 10th, 2021

DOI: https://doi.org/10.21203/rs.3.rs-860309/v1

License: (c) (1) This work is licensed under a Creative Commons Attribution 4.0 International License. Read Full License

Version of Record: A version of this preprint was published at Nature Communications on September 2nd, 2022. See the published version at https://doi.org/10.1038/s41467-022-32819-7. 


\section{Microspectroscopic visualization of how biochar elevates the soil organic carbon ceiling}

Zhe (Han) Weng ${ }^{1,2,3,4}$, Lukas Van Zwieten ${ }^{1,5 \star}$, Michael T. Rose ${ }^{1}$, Bhupinder Pal Singh ${ }^{6}$, Ehsan Tavakkoli Stephen Joseph ${ }^{8}$, Lynne M. Macdonald ${ }^{9}$, Stephen Kimber ${ }^{1}$, Stephen Morris ${ }^{1}$, Terry J. Rose ${ }^{5}$, Braulio S Archanjo $^{10}$, Caixian Tang ${ }^{3}$, Ashley Franks ${ }^{11,12}$, Hui Diao ${ }^{13}$, Peter M. Kopittke ${ }^{4}$, Annette Cowie 2,14

${ }^{1}$ NSW Department of Primary Industries, Wollongbar Primary Industries Institute, Wollongbar, NSW 2477, Australia ${ }^{2}$ School of Environmental and Rural Sciences, University of New England, Armidale, NSW 2351, Australia

${ }^{3}$ Department of Animal, Plant \& Soil Sciences, Centre for AgriBioscience, La Trobe University, Melbourne, Vic 3086, Australia ${ }^{4}$ School of Agriculture and Food Sciences, The University of Queensland, St. Lucia, Queensland 4072, Australia

${ }^{5}$ Southern Cross University, East Lismore, NSW 2480, Australia

${ }^{6}$ NSW Department of Primary Industries, Elizabeth Macarthur Agricultural Institute, Woodbridge Rd, Menangle, NSW 2568, Australia

${ }^{7}$ NSW Department of Primary Industries, Wagga Wagga Agriculture Institute, Wagga Wagga, NSW 2650, Australia

8University of New South Wales, Sydney, NSW 2052, Australia

${ }^{9} \mathrm{CSIRO}$ Agriculture \& Food, Waite campus, Glen Osmond, SA 5064, Australia

${ }^{10}$ Divisão de Metrologia de Materiais - DIMAT, Instituto Nacional de Metrologia, Normalização e Qualidade Industrial INMETRO, Duque de Caxias, RJ, 25250-020, Brazil

${ }^{11}$ Department of Physiology, Anatomy and Microbiology, La Trobe University, Melbourne, Vic 3086, Australia

${ }^{12}$ Centre for Future Landscapes, La Trobe University, Melbourne, Vic 3086, Australia

${ }^{13}$ Centre for Microscopy and Microanalysis, The University of Queensland, QLD, 4072, Australia

${ }^{14}$ NSW Department of Primary Industries/ University of New England, Armidale, NSW 2351, Australia

*e-mail: lukas.van.zwieten@dpi.nsw.gov.au 
1 The soil carbon saturation concept suggests an upper limit to store soil organic carbon (SOC), set by the mechanisms that protect soil organic matter from decomposition. Biochar has the capacity to protect new $\mathrm{C}$ including rhizodeposits and microbial necromass. However, the decadal scale mechanisms by which biochar influences the molecular diversity, spatial heterogeneity, and temporal changes of SOC persistence remain unresolved. Here we show that the soil C saturation ceiling of a Ferralsol under subtropical pasture could be elevated by $2 \mathrm{Mg}$ (new) $\mathrm{C} \mathrm{ha}^{-1}$ by the application of Eucalyptus saligna biochar $\mathbf{8 . 2}$ years after the first application. Using one, two-, and three-dimensional analyses, significant increases were observed in the spatial distribution of rootderived ${ }^{13} \mathrm{C}$ in microaggregates $(53-250 \mu \mathrm{m}, 11 \%)$ and new $\mathrm{C}$ protected in mineral fractions $(<53 \mu \mathrm{m}$, $5 \%$ ). Microbial C-use efficiency was concomitantly improved by lowering specific enzyme activities, contributing to the decreased mineralization of native SOC by $18 \%$. We provide evidence that the global SOC ceiling can be elevated using biochar in Ferralsols by 0.01-0.1 $\mathrm{Pg}$ new $\mathrm{C} \mathrm{yr}^{-1}$.

Main

Human activities risk releasing $260 \mathrm{Pg}$ of carbon (C) as carbon dioxide $\left(\mathrm{CO}_{2}\right)$ globally that is irrecoverable on a timescale relevant to avoiding profound climate impacts ${ }^{1,2}$. Agricultural soils contribute an average of $2 \mathrm{MgCl}$ lost ha- $\mathrm{yr}^{-1}$ globally-5. It has been estimated that $122 \mathrm{Mg}$ soil organic $\mathrm{C}(\mathrm{SOC}) \mathrm{ha}^{-1}$ to $1 \mathrm{~m}$ depth has been lost over $1 \mathrm{Mha}$ of land converted to tropical grasslands ${ }^{6}$, with 40 $\%$ of this area occurring on Ferralsols ${ }^{7}$. To meet the Paris Agreement of limiting global warming to below $2^{\circ} \mathrm{C}$, the Intergovernmental Panel on Climate Change has shown that $\mathrm{CO}_{2}$ removal (CDR) techniques are urgently needed ${ }^{8,9}$.

Soil $\mathrm{C}$ management ${ }^{4-6}$ and the application of biochar $^{10}$ are appealing $\mathrm{CDRs}^{9,11}$ as they also improve soil health, sustain agricultural productivity ${ }^{12,13}$, and increase resilience of ecosystem services ${ }^{14,15}$. Protecting and rebuilding soil $\mathrm{C}$ could draw down $5.5 \mathrm{Pg} \mathrm{CO}_{2} \mathrm{yr}^{-1}$, representing $25 \%$ of the potential of natural climate solutions to deliver CDR through conservation, restoration, and improved land 
management practices ${ }^{6}$. However, there are biophysical and socio-economic barriers to CDR with SOC management ${ }^{4,6,16,17}$.

Biochar is recognized as a CDR because of its persistence ${ }^{9,11}$ in the environment. The pyrolysis of biomass can deliver bioenergy outcomes, as well as agronomic and non- $\mathrm{CO}_{2}$ greenhouse gas benefits through use of biochar as a soil amendment ${ }^{18-22}$. Biochar systems generally show life cycle climate change impacts of emissions reduction in the range of $0.4-1.2 \mathrm{Mg} \mathrm{CO}_{2} \mathrm{e} \mathrm{Mg}^{-1} \mathrm{dry}_{\text {feedstock }}{ }^{23}$.

Organo-mineral interactions can increase SOC persistence, in some cases over a millennial timescale $\mathrm{e}^{24,25}$. There is a general understanding of the effect of microbial activity ${ }^{26}$ and mineral protection $^{27}$ on SOC storage. However, there are knowledge gaps on the contribution of molecular diversity of organic compounds, fine-scale spatial heterogeneity, and temporal variability in soil conditions. Such composition-space-time interactions influence the accessibility of decomposer communities to the substrate ${ }^{28,29}$. Here, we propose a mechanism by which biochar acts as a biocatalyst to accelerate the formation of organo-mineral and organo-organic interfaces in microaggregates $(53-250 \mu \mathrm{m})$ and mineral protection of SOC (Fig. 1). Biochar can sorb root-derived C (rhizodeposits) and form biofilms on its surfaces. The very fine layer of soil minerals that subsequently builds on the surfaces of biochar as it ages in soil ${ }^{30-32}$ protects rhizodeposits from microbial metabolism ${ }^{33,34}$, and at the same time incorporates microbial necromass ${ }^{35-38}$. This coating can desorb from the surface during aggregate turnover or in response to a change in soil conditions such as $\mathrm{pH}$, redox and moisture ${ }^{39}$. The rhizodeposits and microbial necromass are then captured in microaggregates ${ }^{35,40,41}$ (e.g. $\left.<250 \mu \mathrm{m}\right)$. A new coating can then form in its place. These processes repeat, building rhizodeposits in soil over time (Fig. 1). We examine these processes in detail to quantify the potential of biochar to elevate the SOC storage ceiling. To do this, we applied Eucalyptus saligna biochar $\left(550^{\circ} \mathrm{C}\right)$ to a historic field site established in $2006^{41}$ (Ferralsol under managed subtropical pasture). The mechanisms (Fig. 1) that we tested included the negative priming via higher microbial C-use efficiency and restricted access to substrates, and enhanced mineral protection via 
catalytic biochar surfaces. We demonstrate the importance of fine-scale spatial heterogeneity and temporal variability of diverse $\mathrm{C}$ functional groups in association with mineral fractions for building and protecting rhizodeposits over a decade.

\section{Elevating SOC storage capacity}

We hypothesize that biochar enhances the protective mechanisms for soil organic matter (SOM), and that a greater $\mathrm{C}$ storage capacity can therefore be obtained through strategic applications of biochar. The field site was converted to managed pasture from subtropical forest 100 years ago. This led to a loss of $17 \%$ of the original soil $\mathrm{C}$ stock compared to the adjacent native rainforest (data not shown). To quantify elevated C storage capacity, we measured soil C stocks in the managed pasture over 9.5 years (Table S1) from four treatments: (1) biochar applied to a part of the historical biochar plots 8.2 years after the trial was established ("recent + historical"); (2) biochar applied to a part of the control plots 8.2 years after the trial was established ("recent"); (3) biochar applied 8.2 years previously ("historical"); and (4) nil biochar plots ("control").

All field plots were managed via annual fertilizer application at the start of winter, coinciding with over sowing by annual ryegrass (Methods). The total soil C stock in the unamended pasture soil (control) did not change over 9.5 years $^{41,42,43}$ (Fig. 2a; $P>0.05$ ) and remained at $35 \mathrm{Mg} \mathrm{Cha}^{-1}$ in the $0-100 \mathrm{~mm}$ layer when sampled at 8.2 and 9.5 years after the field trial was set-up. The original application of Eucalyptus saligna biochar $\left(550^{\circ} \mathrm{C}\right)$ in 2006 resulted in a rapid increase in soil C to $40 \mathrm{Mg} \mathrm{Cha}^{-1}(10 \mathrm{Mg}$ biochar ha- ${ }^{-1}, 76 \% \mathrm{C}, 7.6 \mathrm{Mg}$ biochar-C) and SOC continued to increase, plateauing at $50 \mathrm{Mg} \mathrm{C} \mathrm{ha-1}$ at 8.2 years ("historical"). When recent biochar amendment was incorporated into the plots at the same dose after 8.2 years following the original application ("recent + historical"), the C stock immediately increased from 50 to $56 \mathrm{Mg} \mathrm{C}$ ha ${ }^{-1}$ (Fig. 2a) because of the $C$ added from biochar. The $C$ stock then continued to increase further to $58 \mathrm{MgC} \mathrm{ha}^{-1}$ between 8.2 and 9.5 years. This additional $2 \mathrm{Mg} \mathrm{Cha}$ was accumulated because of the increased protection mechanisms for new $C$ provided by the biochar, thus elevating the $\mathrm{C}$ storage ceiling (Fig. 2a). 
The additional $2 \mathrm{Mg}$ new C ha-1 (Fig. 2a) can be explained by negative priming of SOC mineralization (Fig. 2b). Comparing the net cumulative SOC mineralization where there was a recent application of biochar to the control (defined as priming in this study), the recent biochar amendment to the historical plots ("recent + historical") lowered SOC mineralization (i.e. negative priming) by 89 g $\mathrm{CO}_{2-}$ $\mathrm{C} \mathrm{m}^{-2}$ compared with the recent biochar amendment to the control ("recent") which lowered SOC mineralization by $55 \mathrm{~g} \mathrm{CO}_{2}-\mathrm{C} \mathrm{m}^{-2}\left(P<0.05\right.$, Fig. 2b). Recent biochar initiated a small $\left(3 \mathrm{~g} \mathrm{CO}_{2}-\mathrm{C} \mathrm{m}^{-2}\right)$ positive priming effect, whilst recent + historical biochar immediately triggered negative priming (Fig. 2b). Neither recent + historical or recent had an impact on total respiration or root respiration compared to the control ( $P>0.05$, Figs. S1 \& S2). As a portion of the total $\mathrm{CO}_{2}$ flux, root respiration remained relatively consistent (30-32\%) and was unaffected by treatments $(P>0.05$, Table S2).

The additional $2 \mathrm{Mg} \mathrm{C} \mathrm{ha-1} \mathrm{that} \mathrm{accumulated} \mathrm{between} 8.2$ and 9.5 years because of the recent application of biochar to the historical biochar plots ("recent + historical") accrued through the stabilization of rhizodeposits and microbial necromass (Fig. 3). Recent + historical biochar had a similar proportion of total recovered ${ }^{13} \mathrm{C}(58 \pm 5.7 \%$, Fig. 3a) compared to the historical biochar plots ("historical") $(60 \pm 9.8 \%)$, with this being around $18 \%$ greater than the control $(42 \pm 7.3 \%)$ and the recent biochar amendment ("recent") (45 $\pm 4.5 \%$; Fig. 3b) after the pulse-labelling event at 9.5 years $\left(P<0.05 ;\right.$ Table S3). The increase in belowground ${ }^{13} \mathrm{C}$ recovery could be largely explained by an increase in mineral-protected soil organic matter (M-SOM) associated ${ }^{13} \mathrm{C}(14 \%, P<0.05$, Table S4). Initially, recent + historical biochar nearly doubled the ${ }^{13} \mathrm{C}$ retention in the occluded particulate organic matter (O-POM) fractions $\left(5 \mathrm{mg}{ }^{13} \mathrm{C} \mathrm{m}^{-2}\right)$ of microaggregates $(<250 \mu \mathrm{m})$ and M-SOM fractions $\left(14 \mathrm{mg}^{13} \mathrm{C} \mathrm{m}^{-2}\right)$ of macroaggregates $(250-2000 \mu \mathrm{m})$ at 8.9 years compared to the recent biochar (Figs. S3a \& b). The root-derived ${ }^{13} \mathrm{C}$ from rhizodeposition was accumulated gradually into O-POM in macroaggregates and M-SOM at 9.2 years (Figs. S3c \& d), which was in turn transformed into M-SOM fractions in micro- and macroaggregates by 9.5 years (Figs. S3 e \& f).

\section{Microbial contribution and responses to stabilization of rhizodeposits}



catabolic enzyme activities, metabolic quotient of native SOC (bulk soil) and rhizodeposition $\left({ }^{13} \mathrm{C}\right.$ content), and specific enzyme activity (the ratio of enzyme activity-to-microbial biomass) comparing a recent biochar amendment to the control ("recent") and to the historical biochar plots ("recent + historical"). Microbial biomass was increased by $11 \%$ in the recent + historical biochar compared to the recent biochar between 8.9 and 9.5 years (Table S5a). This might result from the stimulation of microbial co-metabolism ${ }^{31}$ of biochar- $\mathrm{C}$, root- $\mathrm{C}$ and $\mathrm{SOC}$ which induced initial positive priming in the recent biochar amendment (Fig. 2b). The recent + historical biochar had increased substrate-induced respiration for citric, oxalic and malic acids compared to the recent biochar (Microresp, Fig. S4; Table S6). No differences were detected for 12 other substrates. This greater respiration induced by carboxylic acids (e.g. root exudates) may partially explain the higher metabolic quotient associated with bulk SOC and rhizodeposition in the recent biochar $c f$. the recent + historical biochar (Table S5b $\&$ c). The recent + historical biochar might result in higher substrate-use efficiency which supports an earlier establishment of negative priming compared to the recent biochar (Fig. 2b). It was previously shown that the recent biochar significantly increased bacterial diversity and the relative abundance of nitrifiers and bacteria consuming biochar $\mathrm{C}$ after one year, but the soil bacterial communities from the recent + historical plots did not differ from the control ${ }^{33}$. This suggests that the microbial accessibility to SOM might be limited in the recent + historical biochar plots, whereas in the recent biochar, the soil microorganisms had to cope with changes in C-substrate type and availability ${ }^{45}$.

The ratio of enzyme activities to total microbial biomass was lower in both recent + historical biochar and recent biochar compared to the control (Table S7) despite no difference in enzyme activities (Table S8). This suggests that for a given amount of microbial biomass, less enzymes were produced in the biochar-amended soil. A low ratio of extracellular enzymes to microbial biomass can slow down the degradation of native $\mathrm{SOC}^{46}$. This is consistent with increased microbial C-use efficiency (Tables S4b \& c), which may indirectly contribute to the negative priming. It has been suggested that the presence of opportunistic microbes that meet their energy and nutrient demands by exploiting the 
catalytic activities of decomposers could lower the specific enzyme activity ${ }^{46}$. The spatial arrangement between microbes and substrates is critical to this process.

129 To better understand the process of negative priming following biochar application, we examined whether the stabilization of rhizodeposits may be facilitated via protection with the abundant Fe and Al in soil. Root exudates can interact with Fe oxides in the soil to promote the formation organomineral complexes. Aluminum may also protect root- $\mathrm{C}$ from biodegradation. The development of organo-mineral complexes was assessed using three-dimensional focused ion beam (FIB) coupled with scanning electron microscopy (SEM) with energy dispersive X-ray spectroscopy (3D-FIB-SEM-EDS) on intact representative soil aggregates from the recent + historical biochar (Fig. 3c) where $\mathrm{C}$ retention co-located with clay minerals, but, not in the recent biochar (Fig. 3d).

To provide a deeper insight into the molecular diversity of organic compounds and the temporal and lateral arrangement with respect to organo-mineral interfaces, we conducted in situ spectromicroscopic analysis of free water-stable microaggregates $(53-250 \mu \mathrm{m})$ and organo-mineral fractions $(<53 \mu \mathrm{m})$ of the recent + historical biochar and recent biochar, and of field-extracted biochars at micro- and nanoscale. The C functional groups, examined using synchrotron-based soft X-ray (SXR) analyses, from the microaggregates $(53-250 \mu \mathrm{m})$ were dominated by quinones $(284.1 \mathrm{eV})$, aromatic $\mathrm{C}$ (285.2 eV, 1s- $\pi^{*}$ transitions of conjugated C=C), and aliphatic C (287.3 eV) (Fig. 4a). For the mineralprotected fractions $(<53 \mu \mathrm{m})$, two prominent features were the low intensity of quinones and high intensity of aliphatic C (Fig. 4a). The dominant peaks of aliphatic, amide and carboxylic C (287-289 eV) are the direct consequence of deposition of microbial metabolites or debris, exopolysaccharides, and root exudates onto mineral surfaces ${ }^{27,47,48}$. These align with the micro-spatial maps produced from the synchrotron-based infrared (IR) microspectroscopy (Fig. 4b). The close correlation between clay minerals and microbial metabolites on the biochar surface supports SOC stabilization, and highlights the importance of clay minerals for the protection of $\mathrm{SOC}$ and the control of microbial activity. 
The correlation between C forms and clay minerals, confirmed by the IR maps, was further examined on a nanometer scale by directly analyzing the chemical composition of the organo-mineral coatings at the surface and in the pores of field-extracted biochars. Greater intensities of quinones (284.1 eV) and carboxyl $\mathrm{C}-\mathrm{OOH}(288.6 \mathrm{eV})$ were observed in the 9.5-year aged biochar compared with the 1-year aged biochar (Fig. 5a). A high magnification image of the area where the fungi were located inside a biochar fragment shows a high concentration of irregular pores and a coating of organic material (Figs. $5 b$ \& c). Fungi can mine nutrients from minerals by exuding acids ${ }^{49,50}$ which may cause the observed microporosity of organo-mineral-biochar interfaces (Figs. 5b, d, f, h \& Fig. S5). Energy dispersive X-ray spectroscopy (EDS) analysis showed that complex changes had occurred on the surface of the biochar over the one-year period (Figs. 5c, 5g). Positively charged nanoparticulate minerals rich in $\mathrm{Al}, \mathrm{Si}, \mathrm{Ca}, \mathrm{P}$, Fe and other cations were attracted to the surface of the negatively charged areas on the biochar. These positively-charged minerals and elements subsequently attracted negatively-charged organic molecules with detectable concentrations of $\mathrm{C}=\mathrm{C}, \mathrm{C}-\mathrm{OH}, \mathrm{C}-\mathrm{N} / \mathrm{C}=\mathrm{N}, \mathrm{C}=\mathrm{O}, \mathrm{COOH}$ functional groups, quinone bonds and anions thus initiating a process whereby porous clusters are formed on the biochar surface (Figs. 5e, 5i). Similarly, exudates from plants and microorganisms can be deposited around mineral surfaces on the biochar, and cations and minerals can be attracted to these organic molecules. Recent biochar amendment to historical biochar plots would provide unoccupied surfaces and pores in the soil to increase sorption capacity for root exudates ${ }^{51}$, which would then serve as binding agents to further enhance aggregate formation ${ }^{52}$. As these clusters are built up, they may also be detached from the biochar either through fluctuating redox conditions and interaction with microbes or perturbation caused by soil invertebrates ${ }^{30}$.

These biochar micro-sites have a high concentration of free radicals with labile easily-mineralizable organic $\mathrm{C}$ and/or inorganics dissolved from the biochar (Table S9). Colloidal biochar particles, leachate, dissolved native OM and rhizodeposits may be further stabilized separately or held together via cation bridging with $\mathrm{Ca}^{2+}$, or with $\mathrm{Al}$ and Fe oxyhydroxides ${ }^{53,54,55}$ and organo-organic interactions at the nanometer scale ${ }^{56}$ (Figs. 5e, 5i). These processes may be encouraged by oxidation of the biochar 
surface as it ages in soil ${ }^{36,37}$. This is supported by our LC-OCD results where dissolved hydrophobic C fractions and building blocks (medium molecular weight) were greater in the recent + historical biochar compared to the recent biochar (Fig. 5j; Table S10). The analysis of the surface of the 9.5-year aged biochar by C-edge EELS and XPS indicated that most of the oxidized C species were formed in the organo-mineral coating. The concentrations of the different functional groups appear to be influenced by the presence of nanophase Fe, Si and Al oxides ${ }^{56}$ (Fig. 5i).

\section{Global impact of elevating the soil carbon ceiling}

Building SOC is a global priority ${ }^{9}$, and our results showed that the SOC storage ceiling can be elevated through single or multiple applications of biochars. We observed a plateau in rhizodeposit accumulation rate over 9.5 years in the historical biochar plots (Fig. $2 a ; y=4.24 \ln (x)+17.6 ; R^{2}=0.95$ ) which implies that the system was approaching a new (16\% higher) equilibrium for SOC storage, ten years after the initial application. We showed that a strategic application of $10 \mathrm{Mg}$ biochar ha-1 after 8.2 years raised the $\mathrm{SOC}$ storage ceiling by a further $2 \mathrm{MgC} \mathrm{ha}^{-1}$. In summary, this Rhodic Ferralsol under the managed pasture had a C storage capacity of $35 \mathrm{Mg} \mathrm{Cha}^{-1}$ in the surface soil, which increased to $44 \mathrm{Mg} \mathrm{Cha}^{-1}$ one year following the application of biochar, which further increased to 50 $\mathrm{Mg} \mathrm{C} \mathrm{ha}{ }^{-1}$ after nearly a decade. The $\mathrm{C}$ storage ceiling was further raised to $59 \mathrm{Mg} \mathrm{C}$ ha-1 $^{-1}$ where biochar was applied to the historically amended field plots. Of this $\mathrm{C}$ storage, $7.6 \mathrm{Mg} \mathrm{C} \mathrm{ha}^{-1}$ was attributed to the addition of $\mathrm{C}$ from biochar, while $2 \mathrm{MgC}$ ha-1 was attributed to the stabilization of new $\mathrm{C}$.

The long-term stabilization of rhizodeposits by biochar after 9.5 years has significant implications for elevating the SOC ceiling. Plants release $\sim 50 \%$ of photosynthetically fixed C into the soil, which is available for microbial growth ${ }^{57-59}$. Global grasslands annually contribute $0.04 \mathrm{Pg} \mathrm{C}$ to $\mathrm{SOC}^{6}$. The retention and stabilization of belowground $\mathrm{C}$ by biochar could play an important part in a natural climate solution for tropical grasslands, which occupy 0.7 Gha of land with an estimated global C content of $30 \mathrm{Pg} \mathrm{C}$. Here we showed a $16 \%$ increase in retention of new $\mathrm{C}$ in the recent + historical plots compared with the control via the stabilization of root-derived ${ }^{13} \mathrm{C}$ in microaggregates $(53-250$ 
$\mu \mathrm{m}, 11 \%$ ) and microbial products and rhizodeposits protected in mineral fractions ( $<53 \mu \mathrm{m}, 5 \%$ ) (Fig. in stabilization based on the global projected biochar production. We estimated the strategic application of biochar can increase SOC storage capacity in Ferralsols by 0.01-0.1 Pg C yr-1 worldwide (Supplementary information). This mechanism would increase the global mitigation potential using biochar as a soil amendment, estimated at $1.3 \mathrm{Pg} \mathrm{C} \mathrm{yr}^{-1}$ (centurial average; Woolf et al. 2010), by another 0.8-7.7\%.

In our study, we raised the SOC storage capacity in a subtropical pasture with a strategic application of a Eucalyptus saligna biochar $\left(550^{\circ} \mathrm{C}\right) 8.2$ years following the original biochar application. Of importance to building soil C stocks, the strategic application of biochar in the aged plots resulted in $16 \%$ more new C (i.e. microbial products and rhizodeposits) being stored as soil C in both microaggregates (53-250 $\mu \mathrm{m})$ and mineral fractions $(<53 \mu \mathrm{m})$. Microbial C-use efficiency was improved by lowering the specific enzyme activity and slowing down degradation of SOC and rhizodeposits (negative priming). Our in situ spectromicroscopic analyses suggest that the catalytic biochar surfaces accelerated the micro- and nanoscale heterogeneity and temporal variability for new $\mathrm{C}$ storage.

\section{Methods}

Field site details

The field experiment was situated at the Wollongbar Primary Industries Institute $\left(28^{\circ} 49^{\prime} \mathrm{S}, 153^{\circ} 23^{\prime} \mathrm{E}\right.$, elevation: $140 \mathrm{~m}$ ), Wollongbar, New South Wales, Australia. The classification and properties of the soil can be found in Weng et al. (2015). Briefly, the Rhodic Ferralsol is fine-textured and Fe-rich mineral soil dominated by kaolinite, gibbsite and goethite. The $100-\mathrm{mm}$ topsoil had a $\mathrm{pH}_{\mathrm{Cacl}}$ of 4.5 with total C of $35 \mathrm{~g} \mathrm{~kg}^{-1}$, total Fe $84 \mathrm{~g} \mathrm{~kg}^{-1}$, and total Al $67 \mathrm{~g} \mathrm{~kg}^{-1}$. Details of the initial field site setup in 2006 can be found in Slavich et al. (2013). The treatments ( $n=3$ ) included (1) Eucalyptus saligna biochar incorporated into the topsoil $\left(0-100 \mathrm{~mm}\right.$ ) at $10 \mathrm{t} \mathrm{ha}^{-1}$ (eq. $1 \% \mathrm{w} / \mathrm{w}$, bulk density of $1 \mathrm{~g} \mathrm{~cm}^{-3}$ ) plus NPK 
fertilizer and (2) NPK only (control). The biochar was derived from a single source of above-ground biomass of mature Eucalyptus saligna and pyrolyzed at $550{ }^{\circ} \mathrm{C}$ with a residence time of 30 mins (Pacific Pyrolysis, NSW, Australia). The physicochemical properties of the biochar can be found in Slavich et al. (2013). A tetraploid annual ryegrass (Lolium multiflorum) was broadcast at a seeding rate of $35 \mathrm{~kg}$ ha ${ }^{-1}$ and repeated annually. Urea was applied at $46 \mathrm{~kg} \mathrm{~N} \mathrm{ha}^{-1}$ on six occasions ( $276 \mathrm{~kg} \mathrm{ha}^{-1}$ in total) between winter and spring each year following manual cuts of the pasture to simulate grazing. Basal nutrients were applied annually at sowing (Slavich et al. 2013).

In April 2014, the control (NPK only) and 8.2-year-old biochar (Eucalyptus saligna) plots were superimposed with nine subplots $(0.5 \mathrm{~m} \times 0.5 \mathrm{~m})$ (Weng et al. 2017). Four treatments were: (1) Recent biochar to historical biochar plots (biochar applied to a part of the historical biochar plots 8.2 years after the trial was established; "recent + historical"); (2) Recent biochar amendment (biochar applied to a part of the control plots 8.2 years after the trial was established, "recent"); (3) Historical biochar amendment (biochar applied 8.2 years previously, "historical"); and (4) Control (nil biochar plots). There was one subplot per field replicate and a total of three field replicates. The biochar added to the control and aged plots was taken from the biochar 'batch' applied in 2006, which had been airdried and archived in sealed $200 \mathrm{~L}$ steel containers at room temperature. The details of the subplot set up and installation of belowground respiration collars can be found in Weng et al. (2015). Bulk density of the biochar was $0.332 \mathrm{~g} \mathrm{~cm}^{-1}$ measured using a method described in Quin et al. (2014). The weight of soil-biochar mixture in the topsoil $(100-\mathrm{mm})$ was determined based on the bulk density assessed in each treatment. Before application, the biochar was sieved to $<2 \mathrm{~mm}$. The soil/biochar mixture was carefully packed into the subplots. The control subplots were also excavated and repacked to a bulk density of $1 \mathrm{~g} \mathrm{~cm}^{-3}$. A root signature sand collar ( $50 \mathrm{~mm}$ diameter) was installed in each of the control subplots to measure the $\delta^{13} \mathrm{C}$ signature of root respiration. It was packed with acidwashed sand and planted with ryegrass (i.e. a down-sized version of the soil plus root respiration collar). Similarly, a biochar+root signature sand collar was packed with a biochar-sand mixture (1 \% $w / w)$ in each of the recent + historical biochar subplots. To maintain the root growth into the collars, 
NPK fertilizers were applied at the same dose as in Slavich et al. (2013). This study employed the same pasture management regime as Slavich et al. (2013), in terms of ryegrass sowing, NPK applications and weed control.

\section{Periodic ${ }^{13} \mathrm{C}$ pulse labelling to quantify SOC mineralization and root respiration}

To understand how plant-biochar-soil interactions affect $\mathrm{SOC}$ priming, ${ }^{13} \mathrm{CO}_{2}$ pulse labelling campaigns were conducted on three occasions: 12 June 2014, 01 August 2014 and 30 July 2015. The procedure of the pulse labelling experiment and a detailed description of quantification of SOC mineralization and root respiration using three-pool C partitioning can be found in Weng et al. $(2015,2018)$.

Soil sampling was carried out at 8.9, 9.2 and 9.5 years following the first biochar application in 2006. Intact soil cores (40 $\mathrm{mm}$ in diameter) were sampled to $80 \mathrm{~mm}$ depth within each subplot but outside the respiration collar area to reduce disturbance. The sampled areas were avoided in the ensuing sampling events. The sample was mixed evenly and analyzed for $\mathrm{pH}$, total soil organic $\mathrm{C}$, and microbial biomass carbon $(\mathrm{MBC})$. Soil pH was measured on the samples prepared for the enzyme assay $(1: 5 \mathrm{w} / \mathrm{w}$ ratio in distilled water with constant stirring using a vortex) using an IntelliCAL PHC101 pH probe on a Hach HQ40d portable meter (Loveland, Colorado, USA). The analytical procedures for SOC and MBC can be found in Weng et al. 2015. The remaining soil was stored at $-20^{\circ} \mathrm{C}$.

At the 15-month soil sampling event, fresh soil was also taken from the soil respiration collars (i.e. unplanted) and soil+root respiration collars (i.e. planted) to quantify the effect of plant-biochar-soil interactions on catabolic enzyme activity, substrate-induced respiration, and MBC. The MBC was analyzed using the chloroform fumigation method (Van Zwieten et al. 2010). Metabolic quotient of total $\mathrm{C}$ or rhizodeposits was then quantified as the ratio of respiration (native $\mathrm{SOC}$ or ${ }^{13} \mathrm{C}$-labelled root respiration) over the total $\mathrm{MBC}$. The metabolic quotient has been used as an indicator of C-use efficiency (Fang et al., 2018). Detailed calculations for determining rhizodeposit-derived respiration are given in Weng et al. (2015). 
277 The rhizosphere priming of native SOC from the biochar-plant-soil interactions was quantified using a three-pool C partitioning model. Specialized respiration collars were used to isolate soil plus root respiration from shoot respiration ${ }^{41,42}$. Native SOC mineralization was separated using the $\delta^{13} \mathrm{C}$ signature of biochar plus root (biochar plus root sand collars, Supplementary Information) and total respiration (biochar plus soil plus root collars) after pulse labelling. Moisture content was maintained between $60-80 \%$ field capacity in the root collars to minimize potential $\mathrm{C}$ isotopic fractionation during photosynthesis caused by water stress ${ }^{44}$. The $\delta^{13} \mathrm{C}$ signatures of extracted field-aged biochar and fresh biochar (the same biochar archived in a sealed container for 8.2 years) were both $-25 \pm 0.1 \%$. Any interactive effect of biochar and root on the $\delta^{13} \mathrm{C}$ signature of soil would be surpassed by a greater level of $\delta^{13} \mathrm{C}$ enrichment of the root component compared with any isotopic signature contribution from soil and biochar to the $\delta^{13} \mathrm{C}$ signature of the total respiration. A sensitivity analysis of $\mathrm{C}$ source partitioning was performed to assess the impact of plant-biochar ( $\mathrm{C}_{3}$-dominated)-soil interactions on $\delta^{13} \mathrm{C}$ signatures of soil (a mixture of $C_{3}$ and $C_{4}$ pools). Errors generated from isotopic partitioning were propagated using the first order Tyler series approximations of the variances of native SOC mineralization.

The recovery of ${ }^{13} \mathrm{C}$ in various $\mathrm{SOC}$ pools at time $\mathrm{t}\left(\right.$ i.e. $\mathrm{A}^{13} \mathrm{C}_{\mathrm{i}, \mathrm{t}}$, in \%) was calculated by dividing the amount of ${ }^{13} \mathrm{C}\left(\mathrm{g} \mathrm{m}^{-2}\right)$ in a specific $\mathrm{C}$ pool (i.e. $\left.\mathrm{C}_{\mathrm{i}}\right)$ by the initial amount of total added ${ }^{13} \mathrm{CO}_{2}\left(\mathrm{~g} \mathrm{~m}^{-2}\right)$ at each labelling event (i.e. $\left.{ }^{13} C_{\text {added }}\right)$ :

$\mathrm{A}^{13} \mathrm{C}_{\mathrm{i}, \mathrm{t}}=\left({ }^{13} \mathrm{C}_{\text {excess, }} \times \mathrm{C}_{\mathrm{i}}\right) /{ }^{13} \mathrm{C}_{\text {added }} \times 100$

where i represents soil plus root respiration, root biomass, soil aggregates or its associated fractions, level at a specific sampling time, $\mathrm{t}$. 
The mineralization of native $\mathrm{SOC}\left(C_{S}\right)$ was calculated using the ${ }^{13} \mathrm{C}$ signature of biochar+root $\left({ }^{13} C_{B+R}\right.$, sand collar) from the plant-biochar-soil systems after pulse labelling:

$C_{S}(\%)=100 *\left(\delta^{13} C_{T}-\delta^{13} C_{B+R}\right) /\left(\delta^{13} C_{S}-\delta^{13} C_{B+R}\right)$

where $\delta^{13} \mathrm{C}_{\mathrm{T}}: \delta^{13} \mathrm{C}$ signature of the total respiration from the planted system after pulse labelling; $\delta^{13} \mathrm{C}_{\mathrm{s}}: \delta^{13} \mathrm{C}$ signature of the soil-derived $\mathrm{CO}_{2}-\mathrm{C}$ evolved from the unplanted control soil without pulse labelling.

The percentage of soil-derived $\mathrm{CO}_{2}-\mathrm{C}$ in the total respiration from the planted control soil $\left(\mathrm{C}_{\mathrm{S}^{\prime}}(\%)\right)$ was determined (Weng et al. 2015):

$C_{S^{\prime}}(\%)=100 *\left(\delta^{13} C_{T^{\prime}}-\delta^{13} C_{R}\right) /\left(\delta^{13} C_{S^{-}} \delta^{13} C_{R}\right)$

where $\delta^{13} \mathrm{C}_{\mathrm{T}^{\prime}}: \delta^{13} \mathrm{C}$ signature of the total respiration from the planted control; $\delta^{13} \mathrm{C}_{\mathrm{s}}$ : the $\delta^{13} \mathrm{C}$ signature of the unplanted control soil; $\delta^{13} C_{R}$ : the $\delta^{13} C$ signature of roots, which was determined from root respiration from the root sand collar as described in Weng et al. (2017).

Similarly, the percentage of soil-derived $\mathrm{CO}_{2}-\mathrm{C}$ in the total respiration from the unplanted biocharamended soil $\left(\mathrm{C}_{\mathrm{S}^{\prime \prime}}(\%)\right)$ was determined:

$C_{S^{\prime \prime}}(\%)=100 *\left(\delta^{13} C_{T^{\prime \prime}}-\delta^{13} C_{B}\right) /\left(\delta^{13} C_{S^{-}} \delta^{13} C_{B}\right)$

where $\delta^{13} \mathrm{C}_{\mathrm{T}^{\prime \prime}}$ : the $\delta^{13} \mathrm{C}$ signature of the total respiration from the unplanted biochar soil. $\delta^{13} \mathrm{C}_{\mathrm{s}}$ : the $\delta^{13} \mathrm{C}$ signature of the unplanted control soil; $\delta^{13} C_{B}$ : the $\delta^{13} C$ signature of either fresh $(-25.02 \pm 0.13$ $\%$ ) or aged biochar $(-25.04 \pm 0.11 \%$ o). Biochars were recovered by hand from field soil samples, thoroughly rinsed with distilled water on a $100 \mu \mathrm{m}$ sieve and oven-dried at $50^{\circ} \mathrm{C}$ for $24 \mathrm{~h}$.

Rhizosphere priming was calculated in two systems:

i. Unamended system (Planted vs. Unplanted) 

- $\quad S O C$ planted, unamended: soil $\mathrm{C}$ mineralization in the planted control calculated by ${ }^{13} \mathrm{C}$-enriched root end-member - $\quad$ SOC unplanted, unamended: soil $\mathrm{C}$ mineralization in the unplanted control Rhizosphere priming in the control soil: $\Delta \mathrm{SOC}_{\text {unamended }}=\left(\mathrm{SOC}_{\text {planted, unamended }}\right)-\left(\mathrm{SOC}_{\text {unplanted, unamended }}\right)$ - $\quad$ SOC planted, amended: soil $\mathrm{C}$ mineralization in the planted biochar soil partitioned from ${ }^{13} \mathrm{C}$ enriched 'Biochar+Root' end-member - $\quad$ SOC unplanted, amended: soil C mineralization in the unplanted biochar soil partitioned from biochar end members Rhizosphere priming in the biochar system:

$\Delta \mathrm{SOC}_{\text {amended }}=\left(\mathrm{SOC}_{\text {planted, amended }}\right)-\left(\mathrm{SOC}_{\text {unplanted, amended }}\right)$ control soils: biochar amendment or the control.

Calculated ${ }^{13} \mathrm{C}$ atom \% ( \%):

${ }^{13} \mathrm{C}$ atom $\%=\left[\left(\delta^{13} \mathrm{C}+1000\right) * \mathrm{R}_{\mathrm{PDB}}\right] * 100 /\left[\left(\delta^{13} \mathrm{C}+1000\right) * \mathrm{R}_{\mathrm{PDB}}+1\right]$

where $\mathrm{R}_{\mathrm{PDB}}=0.01118$. 
341 Because of the uncertainty of the direction of biochar-induced priming of soil carbon and/or

342 rhizodeposits, the contribution of biochar on the ${ }^{13} C$ endmember of $\left(\delta^{13} C_{S}\right)$ was assessed. Therefore, 343 three alternative scenarios of three-pool C partitioning were evaluated:

344 1) dominant positive priming of new $C$ from the $C_{3}$ pasture, where $\delta^{13} C_{s^{\prime}}=-27 \%$ (i.e. the upper 345 boundary, grey dashed line, Fig. 2b);

2) equal native SOC priming and rhizosphere priming, hence, the same ${ }^{13} \mathrm{C}$ signatures of soil+root in the biochar and control plots, where $\delta^{13} C_{S^{\prime}}=\delta^{13} C_{S}$ (i.e. solid lines in Fig. 2b);

3) dominant positive priming of the native $\mathrm{C}_{4}$-dominant SOC, where $\delta^{13} \mathrm{C}_{S_{+} \mathrm{R}^{\prime}}=-13 \%$ o (i.e. the lower boundary, grey dashed line, Fig. 2b).

The boundary conditions were calculated from the published ${ }^{13} \mathrm{C}$ signatures for Scenarios 1 and 3 (Farquhar et al. 1989). The $95 \%$ confidence intervals were the combination of the lowest and highest scenarios $(n=3)$. First order Tyler series of the variances of the percentage of soil respiration, $C_{S}(\%)$, were approximated to propagate errors from isotopic partitioning (Derrien et al. 2014).

\section{Enzyme activity and substrate-induced respiration}

The determination of catabolic enzyme activities using a soil suspension method is described in Weng et al. (2017). Six treatments were derived from the control, the recent + historical biochar and recent biochar plots in both the unplanted (i.e. soil respiration collar) and planted (i.e. soil+ root respiration collar) systems (Table S5, Weng et al., 2017). After 7-d incubation at $40 \%$ water-holding capacity (WHC), the activities of four C-degrading enzymes: ß-glucosidase, xylosidase, cellulase, and N-acetylglucosaminidase, in the soils were analysed using a fluorescent microplate reader (BMG labtech FLUOstar Omega). Specific C enzyme activity was obtained by dividing the activity of individual 
enzymes over the total MBC at each sampling time. These ratios provided an indication of the Cturnover efficiency of the soil microbial community (Kaiser et al., 2015). Substrate-induced respiration was used to measure Community level physiological profiles using the MicroResp ${ }^{\mathrm{TM}}$ method (Campbell et al., 2003) with minor modifications. Fresh soil samples, packed in 96-deepwell plates (around $0.5 \mathrm{~g}$ per well), were prepared in the same manner as the enzyme experiment (i.e. incubation conditions). protocol is detailed in Weng et al. (2017). Fifteen C substrates (Table S6) were selected to represent a broad range of soil and root exudates (Campbell et al. 2003; Chapman et al. 2007).

\section{Aggregate size and density fractionation}

Aggregate size (dry sieving) and density fractionation was conducted based on the method described by Weng et al. (2018). No large macroaggregates (> $2000 \mu \mathrm{m})$ was found in this study. Macroaggregates $(250-2000 \mu \mathrm{m})$ and microaggregates $(<250 \mu \mathrm{m})$ were fractioned into free POM (FPOM, $\left.\rho<1.6 \mathrm{~kg} \mathrm{~m}^{-3}\right)$, occluded POM (O-POM, $(>53 \mu \mathrm{m})$, and mineral-protected soil organic matter (M-SOM, combining silt- and clay-bound SOM, <53 $\mu \mathrm{m}$ ).

\section{Belowground ${ }^{13} \mathrm{C}$ pools}

The $\mathrm{C}$ and $\mathrm{N}$ content, and $\delta^{13} \mathrm{C}$ signatures of bulk soil, aggregates and fractions were measured using a PDZ Europa ANCA-GSL elemental analyzer interfaced to a PDZ Europa 20-20 isotope ratio mass spectrometer (Sercon Ltd., Cheshire, UK) (Weng et al., 2015).

\section{D-FIB-SEM-EDS}

The serial section and EDS Mapping of the soil particle was prepared in a FEI SCIOS focused ion beam/scanning electron microscope (FIB/SEM) DualBeam system. The SCIOS FIB/SEM DualBeam system has a vertical mounted SEM column and an ion column sitting at an angle of 52 degrees with respect to the electron column. The particle was located with the aid of the electron beam. Before 
any milling, one micrometre thick platinum layer was deposited on the sample surface covering the area of interest to prevent it from damage caused by the ion bombardment in the following steps. The smooth finish of the Pt layer would also help to reduce the curtaining effect during the following milling procedure. The serial sectioning of the volume was carried out at $3 \mathrm{nA}$ and $30 \mathrm{kV}$ ion beam current and the EDS mapping were collected at $5 \mathrm{kV}$ and $6.4 \mathrm{nA}$ electron beam current. The voxel size of the SEM images is $84 \mathrm{~nm}(\mathrm{x}) \times 84 \mathrm{~nm}(\mathrm{y}) \times 1000 \mathrm{~nm}$ ( $\mathrm{z}$, slicing thickness).

\section{Synchrotron soft X-ray}

Synchrotron-based soft X-ray (SXR) analysis was performed at the SXR Spectroscopy beamline (14ID) at the Australian Synchrotron on the microaggregate $(53-250 \mu \mathrm{m})$ and mineral fractions $(<53 \mu \mathrm{m})$ from 1) recent biochar-amended plots, and 2) the historically biochar-amended plots; and then biochar recovered from the soil, that is: i) 1-year (aged) and ii) 9.5-year (aged) biochar. The samples were ground to fine powder and mounted on double sided carbon tape affixed to a stainless steel ruler.

The SXR spectra were collected at an angle of $100^{\circ}$ to the beam over a photon energy range of 275$325 \mathrm{eV}$ with a step size of $0.1 \mathrm{eV}$. The energy was calibrated using a graphite standard in the beamline which was collected simultaneously with the $I_{0}$ and sample SXR spectra. The double normalization and a pre- and post-edge linear subtraction (background) were conducted using the Athena software (Stöhr 2013).

\section{Synchrotron IR}

For infrared microspectroscopy, approximately 30 free water-stable microaggregates (53-250 $\mu \mathrm{m})$ and mineral fractions $(<53 \mu \mathrm{m})$ were hand-picked on a glass fibre filter paper and humidified gently over 18 hours (Lehmann et al. 2017; Hernandez-Soriano et al. 2018). The aggregates and fractions were frozen at $-20{ }^{\circ} \mathrm{C}$ before being cryo-ultramicrotomed at $200 \mathrm{~nm}$ using a diamond knife. No embedding media was used. The multiple sections per sample $(n>2)$ were directly collected on $\mathrm{CaF}_{2}$ windows (IR transparent). 
The sections on $\mathrm{CaF}_{2}$ were directly scanned at the IR beamline at the Australian Synchrotron using a Bruker Hyperion 3000 infrared microscope and a V80v Fourier transform infrared spectrometer. The detail of the microscope was described in Hernandez-Soriano et al. (2018). The spectral maps were produced in transmission mode from 64 scans with a resolution of $4 \mathrm{~cm}^{-1}$, step size of $5 \mu \mathrm{m}$. Multiple maps were acquired for each treatment to represent the heterogeneity of the sample.

Maps were processed using the software OPUS 8.2 (Bruker Optik GmbH, Germany), targeting absorbance at $3630 \mathrm{~cm}^{-1}$ (O-H groups of clays), $2920 \mathrm{~cm}^{-1}$ (aliphatic-C), $1600 \mathrm{~cm}^{-1}$ (aromatic-C), and $1035 \mathrm{~cm}^{-1}$ (polysaccharides-C)(Hernandez-Soriano et al. 2018). The area of these four absorbance peaks was integrated to the map. A linear regression was conducted to assess the correlation between clay content and the selected $\mathrm{C}$ functional groups.

Forty biochar particles were extracted from the soil samples per plot and were examined using a Zeiss Sigma Scanning electron microscope. Detailed analysis of 5 particles was carried using a Bruker X-ray Dispersive analyser (EDS). A Cs-corrected FEI Titan 80/300 scanning transmission electron microscope (STEM) working at $80 \mathrm{keV}$, equipped with a Gatan imaging filter Tridiem and an EDX analyzer was utilised to determine the structure and composition of the organo-mineral clusters that had formed on the surface of the aged biochar. Twenty biochar particles were sonicated in ethanol and then a sample of this was placed on a lacey carbon grind as described by Archanjo et al (2017). Detailed examination of 2 clusters was carried out using energy electron loss spectroscopy (EELS) and EDS. Xray photoelectron spectroscopy (XPS) examination of both whole and crushed $(<0.5 \mathrm{~mm}) 1$-year aged particles of biochar was undertaken. Carbon 1s photoelectron peak was decomposed in five components: C1-C5 (Table S9). The first one (C1) centered in $284.6 \mathrm{eV}$, typical of electrons in carbon $s p^{2}$ bounds $(\mathrm{C}=\mathrm{C})$, i.e., delocalized $\mathrm{sp}^{2}$ electrons. For this component, an asymmetrical line shape was used to fit. The asymmetry of the C1 component, known as a "defect peak", is related to the localized $\mathrm{sp}^{2}$ electrons. Electrons of $\mathrm{C}-\mathrm{C}$ or $\mathrm{C}-\mathrm{H}$ bounds typically appear with a binding energy shift of $0.9 \mathrm{eV}$ in 
relation to $\mathrm{sp}^{2}$ delocalized electrons, causing a broadening in the first component. The component $\mathrm{C} 2$, centered in $286.2 \pm 0.2 \mathrm{eV}$ may be attributed to $\mathrm{C}-\mathrm{OH}$ (phenol or hydroxyl groups), ether (C-O-C) or pyrrolic groups $(\mathrm{C}-\mathrm{N})$. Some authors also attribute this component to $\mathrm{Csp}^{3}$ free radicals. The component $\mathrm{C} 3$ is attributed to carbonyl groups $(\mathrm{C}=\mathrm{O})$ centered in $287.5 \pm 0.4 \mathrm{eV}$, the component $\mathrm{C} 4$ is attributed to the carboxyl groups $(\mathrm{COOH})$ centered in $289.1 \pm 0.3 \mathrm{eV}$, and the last one, the component C5 in $291.4 \mathrm{eV}$ is attributed to the shake-up satellite peak, characteristic of $\pi \rightarrow \pi^{*}$ transition of electrons delocalized $\mathrm{sp}^{2}$.

Dissolved organic carbon (DOC) in a water solution was analysed using liquid chromatography organic carbon detection (LC-OCD). Two major fractions were: chromatographable organic carbon (CDOC) and hydrophobic organic carbon (HOC). CDOC (hydrophilic fraction) can be categorized into five fractions as a factor of retention time and molecular weight: i) biopolymers, ii) persistent C-like substances, iii) building blocks, iv) low molecular weight acids and v) low molecular weight neutrals. Samples were extracted in distilled water with a ratio of 1:10 (w/v). The solutions were regularly stirred at $50^{\circ} \mathrm{C}$ for 24 hours before filtration to differentiate solid and liquid phases.

\section{Calculation and statistical analysis}

451 The cumulative SOC, biochar-C mineralization, and root respiration over $466 \mathrm{~d}$ were calculated as the 452 area of a linear interpolation across all measurement points. All statistical analyses were conducted 453 within the $R$ environment ( $R$ development core team 2012). When significant F-tests were obtained $454(P=0.05)$, means were separated using a least significant difference (LSD) test at the 0.05 probability.

\section{Calculations of global implication for increasing soil carbon sink} production of 5.5 to $9.5 \mathrm{Pg}$ biochar by 2100 (Lehmann et al. 2011) with $87 \%$ of the feedstock as 
wood (Jirka and Tomlinson 2013). Using the same application rate in this current study $\left(10 \mathrm{t} \mathrm{ha}^{-1}\right)$, all

wood biochar is assumed to be applied to $0.5-0.8$ Gha in 2100 , accounting for up to $100 \%$ of

tropical Ferralsol and $36 \%$ of tropical grasslands (Lal 2004). The global C sequestration rate in

grasslands is reported between $1.3 \times 10^{-10}$ and $7.6 \times 10^{-10} \mathrm{Pg} \mathrm{C}^{-1} \mathrm{yr}^{-1}$ (Minasny et al. 2017). The

range of $C$ sequestration in grasslands before biochar amendment in 2100 would be around 0.07 -

$0.61 \mathrm{Pg} \mathrm{C}$ (i.e. 0.5 or 0.8 Gha at $1.3 \times 10^{-10}$ and $7.6 \times 10^{-10} \mathrm{Pg} \mathrm{C} \mathrm{ha}^{-1} \mathrm{yr}^{-1}$ ). We found a $16 \%$ increase in

additional soil C sink potential of $0.01-0.1 \mathrm{Pg} C$ (i.e. $16 \%$ of 0.07 or $0.61 \mathrm{Pg} \mathrm{C}$ ).

Fig. 1 Conceptual diagram of the formation of organo-mineral coatings on catalytic biochar surfaces over time in a Rhodic Ferralsol. Biochar can act as a bio-catalyst to accelerate formation of organo-mineral microaggregates $(53-250 \mu \mathrm{m})$ and mineral-protected soil organic matter $(<53 \mu \mathrm{m})$ on its surfaces and induce negative priming of soil organic carbon. Microbes, fungal hyphae and root hairs can further mine minerals within pores via exudation and dissolution. Microbial necromass covered with minerals is then incorporated into the organo-mineral $(<250 \mu \mathrm{m})$ and organo-organic $(<100 \mathrm{~nm})$ interfaces. Following wetting-drying and plant growth cycles, organo mineral and organoorganic aggregates break-off from organic matter because of weak bonding. Once these aggregates

Fig. 2 Belowground carbon dynamics in the longest continuous biochar field experiment. a, Changes in total soil organic carbon ( $\mathrm{SOC}, \mathrm{Mg} \mathrm{Cha}^{-1}$ ) in the control and biochar-amended soils over 9.5 years $(n=3, L S D=1.1)$. Total SOC was measured in the $0-100$ soil layer on an equivalent mass basis using Dumas combustion. $\mathbf{b}$, Rhizosphere priming as difference in cumulative SOC mineralization between planted and unplanted "recent" biochar amended soil or soil with the "recent + historical" biochar. "Recent" biochar is biochar applied to a part of the control plots 8.2 years after the trial was established (closed triangles). The "recent + historical" amendment is biochar applied to a part of the historical biochar plots 8.2 years after the trial was established (open triangles). Confidence intervals (95\%) of "recent" biochar and "recent + historical" biochar amendments are plotted in dashed lines and normalized against the mean squares across all treatments at each sampling event $(n=3)$. For biochar amendment, the $\mathrm{Cl}$ was based on a sensitivity analysis (Online Method Section), which considers the extreme scenarios of contrasting SOC pools (C3 vs. C4 dominated) by differences in $\delta^{13} \mathrm{C}$ signatures. The six arrows represent nitrogen fertilizer additions.

Fig. 3 Allocation and retention of rhizodeposits $\left({ }^{13} \mathrm{C}\right.$-enriched) and three-dimensional elemental distribution in a biochar-amended Ferralsol at 9.5 years. a, 8.2 years after the first application, the biochar-amended soil received a recent dose of biochar at $10 \mathrm{Mg}$ ha-1 to the historical plots ("recent + historical"). The same total amount $\left(190 \mathrm{mg}^{13} \mathrm{C} \mathrm{m}^{-2}\right)$ was supplied in each treatment plot $(\mathrm{n}=3) . \mathbf{b}$, Recent biochar ("recent") was mixed in top $100 \mathrm{~mm}$ of soil at $10 \mathrm{Mg} \mathrm{ha}^{-1}$ one year before measurement. c, 3D FIB-SEM-EDS of an intact soil aggregate $(30 \mu \mathrm{m} \times 25 \mu \mathrm{m} \times 24 \mu \mathrm{m})$ from the "recent + historical" biochar plots. d, 3D FIB-SEM-EDS of an intact soil aggregate (30 $\mu \mathrm{m} \times 20 \mu \mathrm{m} \times$ 
$30 \mu \mathrm{m}$ ) from the "recent" biochar plots. Soil sampling was conducted before and 15 days after labelling. The total recovery of ${ }^{13} \mathrm{C}$ labelling is given, including soil + root respiration, root biomass, free- and occluded particulate matter and mineral fractions.

Fig. 4 Synchrotron-based spectromicroscopic analysis of microaggregates (53-250 $\mu \mathrm{m})$ and mineral fractions $(<53 \mu \mathrm{m})$ in the unamended control and historical biochar-amended plots with recent biochar addition. a, Average SXR spectra of microaggregates $(53-250 \mu \mathrm{m})$ and mineral fractions $(<53$ $\mu \mathrm{m}$ ) with the "recent + historical" and "recent" biochar amendments ( $\mathrm{n}=9, \mathrm{CV} \%<3 \%$ ). b, Semi-thin $(200 \mathrm{~nm})$ sections of free water-stable microaggregates $(53-250 \mu \mathrm{m})$ and mineral fractions $(<53 \mu \mathrm{m})$ isolated from the Ferralsol with the "recent + historical" and "recent" biochar amendments analysed using synchrotron-based IR-microspectroscopy. Spectral maps showing the distribution of polysaccharide-C $\left(1035 \mathrm{~cm}^{-1}\right)$, aromatic- $\mathrm{C}\left(1600 \mathrm{~cm}^{-1}\right)$, aliphatic- $\mathrm{C}\left(2920 \mathrm{~cm}^{-1}\right)$, and mineral-OH (3650 $\mathrm{cm}^{-1}$ ) were obtained from 64 co-added scans $\left(4 \mathrm{~cm}^{-1}\right.$ resolution), lateral resolution $5 \mu \mathrm{m}$ (bars: 50 $\mu \mathrm{m})$. The signal intensity for each molecular group varied according to the colour scale shown. The images on the left are optical micrographs of the semi-thin sections.

Fig 5. In situ spectromicroscopic analysis of the organo-mineral coating on biochar surfaces and pores over time. a, Average SXR spectra of field-extracted "recent" (1-yr aged) and "historical" (9.5yr aged) biochars ( $n=9, C V \%<3 \%)$. b, high magnification secondary electron image of a pore where fungi exist. c, EDS spectrum of the area in b. d, STEM-HAADF image of organo-mineral clusters on the "recent" biochar surface; e, its EELS spectra. $f$, High resolution image of the surface of the organomineral layer inside the pore of the "historical" biochar. $g$, EDS spectrum of the area in $\mathbf{f} . \mathbf{h}$, HAADF image of a deposit attached to the surface of the "historical" biochar. $\mathbf{i}$, its EELS spectra. $\mathbf{j}$, DOC of bulk soils from the "recent + historical" and "recent" biochar amendments analysed with LCOCD. The hydrophilic fraction is further sub-divided into five categories, i: biopolymer, ii: persistent C, iii: building blocks, iv: low molecular weight acids and v: low molecular weight neutrals.

\section{References}

1 Goldstein, A. et al. Protecting irrecoverable carbon in Earth's ecosystems. Nature Climate Change, 1-9 (2020).

2 Cavicchioli, R. et al. Scientists' warning to humanity: microorganisms and climate change. Nature Reviews Microbiology 17, 569-586 (2019).

3 Ogle, S. M., Breidt, F. J. \& Paustian, K. Agricultural management impacts on soil organic carbon storage under moist and dry climatic conditions of temperate and tropical regions. Biogeochemistry 72, 87-121 (2005).

4 Minasny, B. et al. Soil carbon 4 per mille. Geoderma 292, 59-86 (2017).

5 Arneth, A. et al. in Climate Change and Land: an IPCC special report on climate change, desertification, land degradation, sustainable land management, food security, and greenhouse gas fluxes in terrestrial ecosystems 1-98 (Intergovernmental Panel on Climate Change (IPCC), 2019).

6 Bossio, D. et al. The role of soil carbon in natural climate solutions. Nature Sustainability 3, 391-398 (2020).

7 Stocking, M. A. Tropical soils and food security: the next 50 years. Science 302, 1356-1359 (2003).

8 Pachauri, R. K. et al. Climate Change 2014: Synthesis Report. Contribution of Working Groups I, II and III to the Fifth Assessment Report of the Intergovernmental Panel on Climate Change. (2014). 
$5469 \quad$ Allen, M. et al. Global Warming of $1.5^{\circ}$ C. Summary for Policymakers. (2018).

54710 Woolf, D., Amonette, J. E., Street-Perrott, F. A., Lehmann, J. \& Joseph, S. Sustainable biochar to mitigate global climate change. Nature Communications 1, 56 (2010).

11 Masson-Delmotte, V. et al. Global warming of 1.5 C. An IPCC Special Report on the impacts of global warming of 1 (2018).

12 Lal, R. Managing soils and ecosystems for mitigating anthropogenic carbon emissions and advancing global food security. BioScience 60, 708-721, doi:10.1525/bio.2010.60.9.8 (2010).

13 Lal, R. Soil carbon sequestration to mitigate climate change. Geoderma 123, 1-22, doi:10.1016/j.geoderma.2004.01.032 (2004).

14 Lehmann, J., Bossio, D. A., Kögel-Knabner, I. \& Rillig, M. C. The concept and future prospects of soil health. Nature Reviews Earth \& Environment, 1-10 (2020).

15 Amelung, W. et al. Towards a global-scale soil climate mitigation strategy. Nature Communications 11, 1-10 (2020).

16 Chenu, C. et al. Increasing organic stocks in agricultural soils: Knowledge gaps and potential innovations. Soil and Tillage Research 188, 41-52 (2019).

17 Amundson, R. \& Biardeau, L. Opinion: Soil carbon sequestration is an elusive climate mitigation tool. Proceedings of the National Academy of Sciences 115, 11652-11656 (2018).

$18 \mathrm{Ji}, \mathrm{C} .$, Cheng, K., Nayak, D. \& Pan, G. Environmental and economic assessment of crop residue competitive utilization for biochar, briquette fuel and combined heat and power generation. Journal of Cleaner Production 192, 916-923 (2018).

19 Woolf, D., Solomon, D. \& Lehmann, J. Land restoration in food security programmes: synergies with climate change mitigation. Climate Policy 18, 1260-1270 (2018).

20 Woolf, D., Lehmann, J. \& Lee, D. R. Optimal bioenergy power generation for climate change mitigation with or without carbon sequestration. Nature Communications 7, 1-11 (2016).

21 Woolf, D., Amonette, J. E., Street-Perrott, F. A., Lehmann, J. \& Joseph, S. Sustainable biochar to mitigate global climate change. Nature communications 1, 1-9 (2010).

$22 \mathrm{Xu}, \mathrm{X}$. et al. Greenhouse gas mitigation potential in crop production with biochar soil amendment-a carbon footprint assessment for cross-site field experiments from China. Gcb Bioenergy 11, 592-605 (2019).

23 Cowie, A. et al. Biochar, carbon accounting and climate change. (En: Biochar for environmental management: science, technology and ..., 2015).

24 Torn, M. S., Trumbore, S. E., Chadwick, O. A., Vitousek, P. M. \& Hendricks, D. M. Mineral control of soil organic carbon storage and turnover. Nature 389, 170-173, doi:10.1038/38260 (1997).

25 Hemingway, J. D. et al. Mineral protection regulates long-term global preservation of natural organic carbon. Nature 570, 228-231 (2019).

26 Woolf, D. \& Lehmann, J. Microbial models with minimal mineral protection can explain longterm soil organic carbon persistence. Scientific reports 9, 1-8 (2019).

27 Kopittke, P. M. et al. Soil organic matter is stabilized by organo-mineral associations through two key processes: The role of the carbon to nitrogen ratio. Geoderma 357, 113974 (2020).

28 Lehmann, J. \& Kleber, M. The contentious nature of soil organic matter. Nature 528, 60-68, doi:10.1038/nature16069 (2015).

29 Lehmann, J. et al. Persistence of soil organic carbon caused by functional complexity. Nature Geoscience 13, 529-534 (2020).

30 Joseph, S. et al. An investigation into the reactions of biochar in soil. Soil Research 48, 501-515 (2010).

31 Lin, Y., Munroe, P., Joseph, S., Kimber, S. \& Van Zwieten, L. Nanoscale organo-mineral reactions of biochars in ferrosol: an investigation using microscopy. Plant and Soil 357, 369380, doi:10.1007/s11104-012-1169-8 (2012). 
32 Archanjo, B. et al. Nanoscale analyses of the surface structure and composition of biochars extracted from field trials or after co-composting using advanced analytical electron microscopy. Geoderma 294, 70-79 (2017).

33 Nguyen, T. T. N. et al. The effects of short term, long term and reapplication of biochar on soil bacteria. Science of the Total Environment 636, 142-151 (2018).

34 Ding, F. et al. A meta-analysis and critical evaluation of influencing factors on soil carbon priming following biochar amendment. Journal of soils and sediments 18, 1507-1517 (2018).

35 Liang, C., Amelung, W., Lehmann, J., \& Kästner, M. Quantitative assessment of microbial necromass contribution to soil organic matter. Global change biology 25, 3578-3590 (2019).

36 Lehmann, J. et al. Biochar effects on soil biota - A review. Soil Biology \& Biochemistry 43, 18121836, doi:10.1016/j.soilbio.2011.04.022 (2011).

37 Singh, B. P. \& Cowie, A. L. Long-term influence of biochar on native organic carbon mineralisation in a low-carbon clayey soil. Scientific Reports 4, doi:10.1038/srep03687 (2014).

38 Li, X., Wang, T., Chang, S. X., Jiang, X., \& Song, Y. Biochar increases soil microbial biomass but has variable effects on microbial diversity: A meta-analysis. Science of The Total Environment 749, 141593 (2020).

39 Husson, O. Redox potential (Eh) and $\mathrm{pH}$ as drivers of soil/plant/microorganism systems: a transdisciplinary overview pointing to integrative opportunities for agronomy. Plant and Soil 362, 389-417 (2013).

40 Weng, Z. H. et al. The accumulation of rhizodeposits in organo-mineral fractions promoted biochar-induced negative priming of native soil organic carbon in Ferralsol. Soil Biology and Biochemistry 118, 91-96 (2018).

41 Weng, Z. et al. Biochar built soil carbon over a decade by stabilizing rhizodeposits. Nature Clim. Change 7, 371-376, doi:10.1038/nclimate3276

\section{http://www.nature.com/nclimate/journal/v7/n5/abs/nclimate3276.html\#supplementary-} information (2017).

42 Weng, Z. H. et al. Plant-biochar interactions drive the negative priming of soil organic carbon in an annual ryegrass field system. Soil Biology and Biochemistry 90, 111-121 (2015).

43 Slavich, P. et al. Contrasting effects of manure and green waste biochars on the properties of an acidic ferralsol and productivity of a subtropical pasture. Plant and Soil 366, 213-227 (2013).

44 Farquhar, G., Hubick, K., Condon, A. \& Richards, R. in Stable isotopes in ecological research 21-40 (Springer, 1989).

45 Graber, E. R. et al. Biochar impact on development and productivity of pepper and tomato grown in fertigated soilless media. Plant and Soil 337, 481-496, doi:10.1007/s11104-0100544-6 (2010).

46 Kaiser, C., Franklin, O., Richter, A. \& Dieckmann, U. Social dynamics within decomposer communities lead to nitrogen retention and organic matter build-up in soils. Nature Communications 6 (2015).

47 Lehmann, J. et al. Spatial complexity of soil organic matter forms at nanometre scales. Nature Geoscience 1, 238-242 (2008).

48 Lehmann, J. \& Solomon, D. in Developments in soil science Vol. 34 289-312 (Elsevier, 2010).

49 Lybrand, R. A. et al. A coupled microscopy approach to assess the nano-landscape of weathering. Scientific reports 9, 1-14 (2019).

50 Van Hees, P., Jones, D., Jentschke, G. \& Godbold, D. Mobilization of aluminium, iron and silicon by Picea abies and ectomycorrhizas in a forest soil. European Journal of Soil Science 55, 101112 (2004).

51 Kasozi, G. N., Zimmerman, A. R., Nkedi-Kizza, P. \& Gao, B. Catechol and humic acid sorption onto a range of laboratory-produced black carbons (biochars). Environmental Science \& Technology 44, 6189-6195 (2010). 
52 Rasse, D. P., Rumpel, C. \& Dignac, M.-F. Is soil carbon mostly root carbon? Mechanisms for a specific stabilisation. Plant and Soil 269, 341-356 (2005).

53 Violante, A., Barberis, E., Pigna, M. \& Boero, V. Factors affecting the formation, nature, and properties of iron precipitation products at the soil-root interface. Journal of Plant Nutrition 26, 1889-1908 (2003).

54 Glaser, B., Balashov, E., Haumaier, L., Guggenberger, G. \& Zech, W. Black carbon in density fractions of anthropogenic soils of the Brazilian Amazon region. Organic Geochemistry 31, 669-678 (2000).

55 Czimczik, C. I. \& Masiello, C. A. Controls on black carbon storage in soils. Global Biogeochemical Cycles 21 (2007).

56 Possinger, A. R., Zachman, M. J., Enders, A., Levin, B. D., Muller, D. A., Kourkoutis, L. F., \& Lehmann, J. Organo-organic and organo-mineral interfaces in soil at the nanometer scale. Nature Communications 11, 1-11 (2020).

57 Huang, P.-M., Wang, M.-K. \& Chiu, C.-Y. Soil mineral-organic matter-microbe interactions: impacts on biogeochemical processes and biodiversity in soils. Pedobiologia 49, 609-635 (2005).

58 Keiluweit, M. et al. Mineral protection of soil carbon counteracted by root exudates. Nature Climate Change 5, 588-595 (2015).

59 Tang, J. \& Riley, W. J. Weaker soil carbon-climate feedbacks resulting from microbial and abiotic interactions. Nature Climate Change 5, 56-60 (2015).

60 Schmidt, M. W. et al. Persistence of soil organic matter as an ecosystem property. Nature 478, 49-56 (2011).

\section{Acknowledgements}

The authors thank the Australian Government, Department of Agriculture and Water Resources for supporting the National Biochar Initiatives (2009-2012, 2012-2014) which co-funded this research.

We are particularly grateful to Dr. Peter Slavich, as one of the key founders of this long-term field experiment for providing insightful comments on the initial draft. Part of this research was undertaken on the Soft X-ray spectroscopy beamline and the Infrared microscopy beamline at the Australian Synchrotron, part of ANSTO (grant numbers AS1_SXR_15754 and AS1_IRM_15940). We thank the beamline scientists, Drs Bruce Cowie and Lars Thomsen, for their technical support on the soft $\mathrm{x}$ ray analysis and Drs Mark Tobin, Annaleise Klein and Jitraporn (Pimm) Vongsvivut, for their technical support on the infrared microscopy analysis. Part of the research is funded by La Trobe University's Research Focus Area in Securing Food, Water and the Environment (Grant Ready: SFWE RFA 2000004295; Collaboration Ready: SFWE RFA 2000004349). We also appreciate the technical support from Scott Petty and Josh Rust for maintaining this field experiment over the past decade, and laboratory support from Nichole Morris. We also thank Dr Carlos Achete from INMETRO, Brazil and Dr 
681 Bin Gong from the University of New South Wales, Australia, for performing XPS analysis of biochars

682 and soils, Dr Sarasadat Taherymoosavi from the University of New South Wales, Australia, for technical 683 assistance in LC-OCD analysis. We acknowledge the intellectual contribution from Prof Johannes 684 Lehmann for discussions on the potential mechanisms of biochar-induced stabilization of 685 rhizodeposits.

\section{Author contributions}

687 ZW drafted and wrote the manuscript, experimental design, set-up and conducted experiments, and 688 data collection and analysis; LVZ, BPS and LMM wrote the manuscript, aided in experimental design, 689 critical revision of the article; SJ, ET, BSA and MTR collected and analyzed data, critical revision of the 690 article; TJT, CT, AF, PMK, SK, SM and AC provided critical revision of the article. All authors provided 691 final approval of the revision to be published.

692 Correspondence and requests for materials should be addressed to LVZ via email: 693 lukas.van.zwieten@dpi.nsw.gov.au 


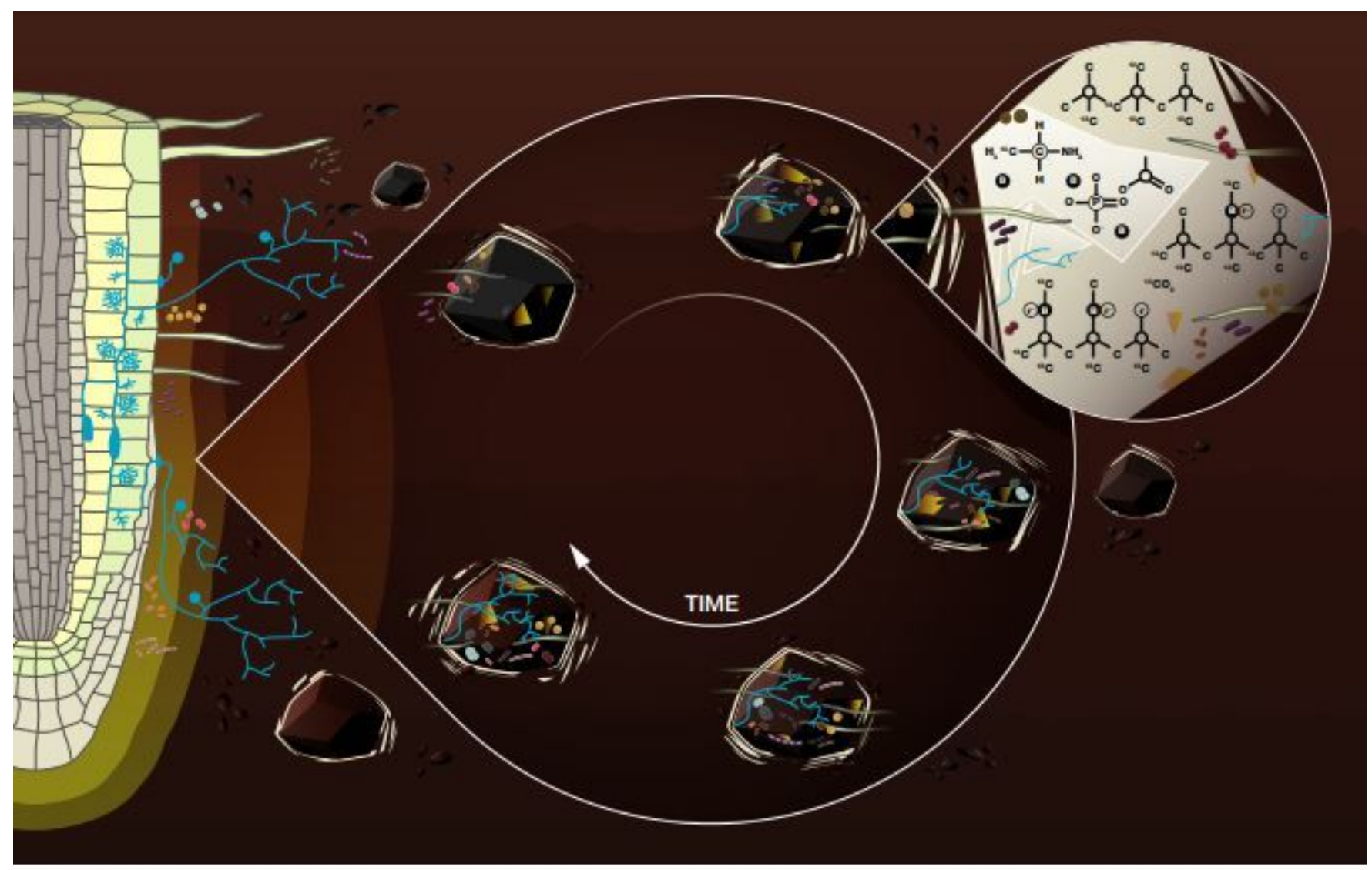

KEY

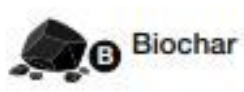

Organo-mineral and organo-organic interfaces
Rhizodeposits $\int \frac{\pi}{2}$ Fungal hyphae
$=-5$

Microbes/ microbial enzymes
(C) Chemically-reduced rhizodeposits

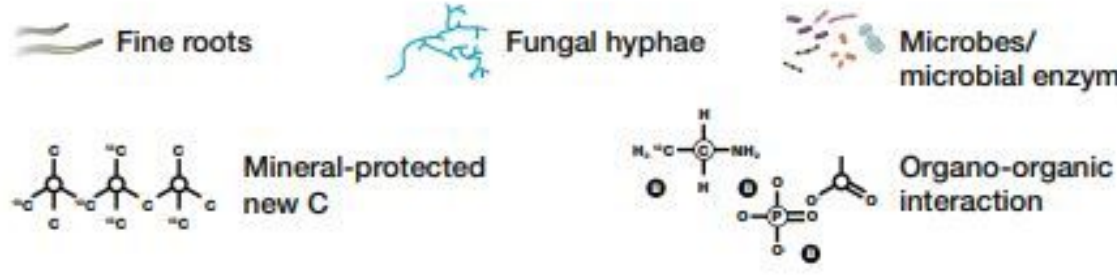

\section{Figure 1}

Conceptual diagram of the formation of organo-mineral coatings on catalytic biochar surfaces over time in a Rhodic Ferralsol. Biochar can act as a bio-catalyst to accelerate formation of organo-mineral microaggregates $(53-250 \mu \mathrm{m})$ and mineral-protected soil organic matter $(<53 \mu \mathrm{m})$ on its surfaces and induce negative priming of soil organic carbon. Microbes, fungal hyphae and root hairs can further mine minerals within pores via exudation and dissolution. Microbial necromass covered with minerals is then incorporated into the organo-mineral $(<250 \mu \mathrm{m})$ and organo-organic $(<100 \mathrm{~nm})$ interfaces. Following wetting-drying and plant growth cycles, organo mineral and organo-organic aggregates break-off from organic matter because of weak bonding. Once these aggregates break off, new mineral layers can form. 


\section{Supplementary Files}

This is a list of supplementary files associated with this preprint. Click to download.

- Videoabstract3DFIBSEMEDXofrhizodepositsretentioninaggregate.mp4

- SupplementaryInformation.pdf 